\title{
Pontos de contato: as relações entre o discurso da extrema direita e a religiosidade evangélica no Brasil
}

\author{
Recebido em 12/05/2020, aprovado em 15/07/2020 \\ DOI: $10.30612 / m v t . v 7 i 12.11918$ \\ Darcon Sousa' \\ Júnior Camilo Sousa²
}

\begin{abstract}
RESUMO:
Este trabalho analisa as conexôes entre os discursos da extrema direita no Brasil e sua forte base de apoio formada pelos evangélicos. Demonstra-se aqui, por meio de pesquisa documental, observacional e bibliográfica, que os principais componentes desses discursos - quais sejam: a revalorização da família tradicional, a predominância da fé sobre a razão, a organização da sociedade via disciplina e ordem e o macarthismo - criaram vínculos com a religiosidade evangélica por meio da exploração de apelos a valores comuns ao extremismo de direita e a uma certa compreensão da fé cristã, predominante entre evangélicos. Conquanto haja tensôes e contradições nessa relação, os evangélicos se constituíram num dos segmentos sociais mais fiéis às teses do governo de extrema direita, emprestando-lhe apoios ideológico, parlamentar e eclesiástico. A intermediação da relação entre extrema direita e a religiosidade evangélica é feita por meio do uso intenso da comunicação política via redes sociais e pela influência de líderes de igrejas comprometidos com o bolsonarismo. Sendo assim, dadas as dimensões da presença evangélica na população brasileira, o comportamento político desses religiosos tem implicaçôes diretas na sustentaçáo do governo Bolsonaro e se apresenta como importante objeto de estudo para investigaçóes que têm como foco o desenvolvimento da democracia brasileira.
\end{abstract}

Palavras-chave: Política. Religião. Democracia.

\section{Points of contact: the relationship between the far-right's discourse and evangelical religiosity in Brazil}

\section{ABSTRACT:}

This work analyzes the connections between the far-right's discourse in Brazil and the solid support it gets from evangelical Christians. Through a documentary, observational and bibliographical

\footnotetext{
1 Doutor em Ciências Sociais, Professor Adjunto da Universidade Federal de Campina Grande, Professor Permanente do Programa de Pós-gradução em Ciência Política da UFCG. Endereço eletrônico: darconsousa@gmail.com.

2 Bacharel em Direito, Mestrando em Ciência Política no Programa de Pós-graduação em Ciência Política da Universidade Federal de Campina Grande. Endereço eletrônico: camilojr1976@hotmail.com.
} 
research, it is shown here that the main components of such a discourse - that is, a revaluation of traditional family, the preponderance of faith over reason, the organization of society via discipline and order, and McCarthyism — managed to establish a link with evangelical religiosity due to its emphasizing common values between the far-right and a kind of understanding of Christian faith that is predominant among evangelicals. Although there are tensions and contradictions in such a relationship, evangelicals have become one of the most faithful social segments to Brazil's far-right government's theses, from which the latter borrows ideological, parliamentary and ecclesiastical support. The intermediation between the far-right and evangelism has been carried out through an intense politically oriented communication via social networks and the influence of religious leaders in churches who are committed to "Bolsonarism". Given the wide presence of evangelicalism in Brazil's population, the political behavior of such people has direct implications in sustaining the Bolsonaro government and is, thus, an important object of study for investigations which focus on developing Brazilian democracy.

Keywords: Politics. Religion. Democracy.

\section{Puntos de contacto: la relación entre el discurso de la derecha y la religiosidad evangélica en Brasil}

\section{RESUMEN:}

Este trabajo analiza las conexiones entre el discurso de la extrema derecha en Brasil y el sólido apoyo que recibe de los cristianos evangélicos. A través de una investigación documental, observacional y bibliográfica, se muestra aquí que los componentes principales de dicho discurso, es decir, una revaluación de la familia tradicional, la preponderancia de la fe sobre la razón, la organización de la sociedad a través de la disciplina y el orden, y el macartismo, logró establecer un vínculo con la religiosidad evangélica debido a que enfatiza los valores comunes entre la extrema derecha y un tipo de comprensión de la fe cristiana que predomina entre los evangélicos. Aunque existen tensiones y contradicciones en esa relación, los evangélicos se han convertido en uno de los segmentos sociales más fieles a las tesis del gobierno de extrema derecha de Brasil, del cual este último toma apoyo ideológico, parlamentario y eclesiástico. La intermediación entre la extrema derecha y el evangelicalismo se ha llevado a cabo a través de una intensa comunicación orientada políticamente a través de las redes sociales y la influencia de los líderes religiosos en las iglesias comprometidas con el "bolsonarismo". Dada la amplia presencia del evangelicalismo en la población de Brasil, el comportamiento político de tales personas tiene implicaciones directas en el mantenimiento del gobierno de Bolsonaro y es, por lo tanto, un importante objeto de estudio para investigaciones que se centran en el desarrollo de la democracia brasileña.

Palabras Clave: Política. Religión. Democracia. 


\section{INTRODUÇÃO}

O golpe parlamentar de 2016 no Brasil consolidou um processo de conspiração contra a democracia, urdido por partidos da direita política, grandes meios de comunicação, elites econômicas e parte do judiciário. A convergência de interesses desses atores sociais estava na determinação em alijar o Partido dos Trabalhadores do poder, maximizando suas contradiçóes e erros, sobretudo os episódios de corrupção dos governos petistas. Para isso, manejaram narrativas, quebraram regras democráticas, criminalizaram a esquerda e disseminaram o ódio social. Acabaram por criar as condiçóes para a emergência da extrema direita, beneficiária do ambiente de deslegitimação da política, do qual resultaram eleiçôes notadamente marcadas por irracionalidade e radicalismo, cujo desfecho foi a vitória de um candidato sem compromisso com a democracia, amparado por uma sólida base de eleitores.

Dentre os grupos sociais responsáveis pela eleição de Jair Bolsonaro, os evangélicos se destacam. Entre eles, 68\% votaram no candidato da extrema direita. Projeçóes feitas antes do segundo turno das eleiçôes indicavam uma diferença em torno dez milhões de votos pró-Bolsonaro (DATAFOLHA, 2018). Embora igualmente bem votado entre os católicos - entre os quais o candidato da extrema-direita mantinha-se num empate técnico de $51 \%$ de intenção de votos contra $49 \%$ de Fernando Haddad (PT) a quatro ou três dias do segundo turno das eleiçóes, conforme pesquisa do Datafolha (2018) divulgada em 26 de outubro daquele ano — , não há comparaçóes cabíveis com a larga preferência dos evangélicos por Bolsonaro, em quem $69 \%$ tinham a intenção de votar, contra apenas $31 \%$ favoráveis ao candidato petista. Vale notar nesse quadro que, segundo cálculos do censo de 2010 do Instituto Brasileiro de Geografia e Estatística, os evangélicos representavam então 22,2\% da populaçáo e, segundo analistas, $30 \%$ do eleitorado.

Há que se considerar, diante desse quadro, que os evangélicos sempre foram uma fração do eleitorado relativamente sub-representada, principalmente se nos focarmos nos segmentos não relacionados ao protestantismo tradicional, mas sim ao evangelismo pentecostal. Por isso mesmo, estes últimos tendem a um comportamento eleitoral mais orientado pelo favoritismo intragrupal, votando em candidatos da própria denominação religiosa, ou de uma "igreja irmâ", em especial no tocante a cargos do legislativo em todos os três níveis (municipal, estadual e federal). A falta de candidatos com esse perfil disputando a presidência da república pode ter sido, portanto, um fator explicativo de por que raramente se tenha notado uma convergência de votos desse grupo num único nome - embora isso tenha, sim, ocorrido num nível elevado o bastante para chamar a atenção na disputa de 2014, em relação à candidatura de Marina Silva, quando esta apresentou uma temporária ascensão na corrida que lhe valeu uma capa da revista Época, de 8 de setembro daquele ano, com a manchete "O poder do voto evangélico".

O fato de não haver, por várias eleiçóes presidenciais, um nome que os representasse de uma perspectiva confessional não significa, no entanto, que já não houvesse então nesse meio um processo de construção discursiva de aversão à esquerda, em especial ao PT. De fato, "[a] demonização evangélica do PT principiou na eleição presidencial de 1989 [segundo estudo de Mariano e Pierucci, de 1992], mas esmaeceu nos governos Lula. Reativou-se após o lançamento dos programas de combate à homofobia e do PLC 122/2006, que visava a criminalizá-la, e do PNDH-3, que propunha a descriminalização do aborto" (MARIANO; GERARDI, 2019, p. 70).

Estas pautas conservadoras, que explicam boa parte do consenso evangélico em torno do nome de Marina Silva em 2014, menos ainda podem ser desconsideradas no fenômeno da ascensão de Jair Bolsonaro até a eleição de 2018. De fato, a convergência dos interesses dos segmentos evangélicos e 
da extrema-direita moralista e reacionária em face do avanço ou da proposição de políticas públicas benéficas a grupos identitários ou minoritários vistas como seguindo na contramão de valores morais dos quais esses grupos se mostram zelosos - caso de questóes como, por exemplo, o casamento homoafetivo, a descriminalização do aborto ou a promoção de uma educação sexual nas escolas públicas voltada para a tolerância à diversidade — só fez aumentar nos últimos anos, não somente no Brasil, mas em diferentes países da América Latina, onde os evangélicos ainda constituem uma parcela minoria, em sociedades predominantemente católicas (BOAS, 2019, p. 2).

Isto posto, é importante ressaltar, ainda, que as eleiçôes de 2018 apresentaram algumas características atípicas, como o crescimento vertiginoso das comunicações digitais via redes sociais, a ocorrência do atentado ao então candidato Jair Bolsonaro e a percepção de que a maioria do eleitorado pretendia escolher alguém que representasse oposição ao establishment político. O espaço para debates no nível da eleição presidencial foi reduzido significativamente, tanto pela legislação que diminuiu o tempo da campanha eleitoral nos veículos de mídia, quanto pelo incidente do qual foi alvo o candidato de extrema-direita.

Nessa ambiência, ao projetar-se como um candidato cristão — tendo inclusive sido batizado por um pastor e político do Partido Social Cristão nas simbólicas águas do rio Jordão em Israel Jair Bolsonaro criou vínculos com o eleitorado evangélico por meio de discursos cujos conteúdos transformaram-se em armas na disputa eleitoral. Os conteúdos desses discursos podem ser agrupados em quatro dimensóes, a saber: "a revalorização da família tradicional", "a predominância da fé sobre a razão", "a organização da sociedade via disciplina e ordem”, e "o macarthismo". Como consequência, a pauta moral, o anti-intelectualismo, o autoritarismo e a demonização da esquerda não só acabaram dominando a comunicação da extrema-direita, como encontraram pronta receptividade no meio evangélico.

A aliança entre esse segmento da sociedade e o então candidato Jair Bolsonaro reduziu as fronteiras entre fé e política, sugerindo que essas esferas teriam interesses complementares e comuns. $\mathrm{O}$ slogan "Brasil acima de tudo e Deus acima de todos" resumia o objetivo de fazer da retórica política uma questão de fé e de impingir ao processo eleitoral um componente religioso que despertou paixôes e construiu uma rígida argamassa de apoio ao bolsonarismo. Para Finchelstein (2020), o populismo bolsonarista, baseado na negação da realidade e na promoção da mentira e de mitos, se apropriou do cristianismo e o descontextualizou para uso de seus propósitos autoritários e repressivos.

Sendo assim, desde a campanha eleitoral, amparado por uma sofisticada e intensa arquitetura de informaçóes que passou ao largo dos meios tradicionais de comunicação, Jair Bolsonaro logrou êxito em construir uma hegemonia entre os evangélicos, o que se traduziu não apenas em votos, mas também em apoio ao governo do presidente eleito. Esse apoio, como interpretamos, se apresenta sob a forma ideológica, parlamentar e eclesiástica. E, em vista disso, este trabalho, a partir da análise de conteúdo de documentos e à luz de uma revisão bibliográfica, pretende descrever as dimensóes discursivas que enlaçaram a extrema direita brasileira à religiosidade evangélica, demonstrando como essa relação construiu uma base social que teve considerável peso na ascendência de Jair Bolsonaro e continua a responder pelos índices de popularidade que sustentam seu governo, a despeito das crises que o acompanham e da crescente insatisfação dos outros setores da sociedade. 


\section{O DISCURSO POLÍTICO DO BOLSONARISMO PARA CONVERTER CRENTES}

A primeira dimensão do conteúdo discursivo da extrema direita brasileira se refere à "revalorização da família tradicional". Antes de abordá-la, é importante reafirmarmos que a construção discursiva da extrema-direita náo pode ser analisada sem a consideração de dois fatores que explicam seu alcance: a ambiência política e social que a favoreceu, conforme mencionado na seção anterior, e a intensa utilizaçáo de uma arquitetura de informação que, difusa e veloz, potencializou uma estratégia de comunicação meticulosamente direcionada a públicos-alvo suscetíveis às suas abordagens. No Brasil, os grandes veículos de comunicação tinham o poder de pautar o debate político durante as eleiçôes nacionais e de privilegiar os candidatos que com eles apresentavam afinidades ideológicas. A candidatura de Jair Bolsonaro, também para projetar-se como antissistêmica, lançou mão das redes sociais e neutralizou a mídia tradicional, experiência já exitosa nos Estados Unidos, com o pleito que deu a vitória a Donald Trump em 2016. Conforme destacou Runciman (2017), a utilização das redes sociais permitiu à extrema-direita criar suas realidades paralelas. Para ser antissistêmico, o discurso precisa operar na lógica da teoria da conspiração, levando as pessoas a desenvolverem paranoias que as fazem a acreditar no que querem, fenômeno que alimenta o populismo.

No Brasil, uma das principais teorias da conspiração elaboradas pelo discurso de extrema-direita foi a de que havia um complô contra a família tradicional. Como consequência, a campanha eleitoral foi tomada por uma pauta moral que atribuía à esquerda política a tolerância e mesmo o estímulo a comportamentos que atentariam contra a família. Nesse sentido, o reconhecimento da união homoafetiva, a descriminalização do aborto e o feminismo foram apresentados como ameaças à permanência da família como núcleo basilar da sociedade. A associação da esquerda com a degeneração da família foi pesquisada pelo cientista político Vítor Araújo, que identificou, entre os eleitores evangélicos pentecostais, uma importância maior dada aos temas morais do que à questáo da distribuição de renda, por exemplo. Situados no extrato social mais pobre da população, esses fiéis são fortemente influenciados pelos líderes de suas igrejas. De acordo com o pesquisador: "A base doutrinária pentecostal estimula um comportamento fundado em um proselitismo de cunho fortemente moralizante. Desse modo, os adeptos do pentecostalismo se veem, não apenas como guardiôes de sua própria santidade, mas também corresponsáveis pela manutenção do padrão moral da sociedade como um todo" (BRPOLÍTICO, 2020).

Neste sentido, Stanley (2018) lembrou que o imaginário de uma família patriarcal como parte das tradiçôes da nação, remetendo a um passado mítico, integra a estratégia de políticos fascistas. $\mathrm{O}$ papel desempenhado pelo líder e pai da nação se coaduna com o do pai de família no patriarcado, o qual exerce autoridade moral sobre seus filhos e esposa. Não por acaso, no corpo do manifesto que fundamenta a criação do novo partido do grupo político que sustenta o governo Bolsonaro, há mençóes claras aos objetivos de restaurar valores tradicionais e culturais da história do país e da família, com destaque para a proteção da mulher em sua condição de mãe e de gestante, aludindo ao combate ao aborto.

A imagem de uma família tradicional como cultivada entre religiosos conservadores, no entanto, na qual o homem é o provedor e as tarefas do lar são atribuídas à mulher que deve submissão àquele que é a "cabeça do lar", encontra-se há muito deslocada da realidade social. Como demonstrou Itaboraí (apud ANDRADE, 2018), a sociedade brasileira apresenta novos arranjos familiares nos quais as mulheres assumiram papéis distintos daqueles de um passado idealizado. Considerando o período entre 1976 e 2012, o percentual de mulheres que trabalham subiu de $25,4 \%$ para $46,4 \%$ entre trabalhadoras rurais e de $34,5 \%$ para $75,5 \%$ entre profissionais de nível superior. 
A quantidade de lares chefiados por mulheres aumentou 67\% entre 2004 e 2014. A busca pela emancipação econômica é parte do universo feminino, sendo a via pela qual a mulher conquista maior autonomia e prospecta uma posição melhor no espaço social. Já as questóes relacionadas ao casamento homoafetivo, aborto e descriminalização das drogas, ainda que façam parte da agenda dos partidos de esquerda, envolvem demandas que ultrapassam as fronteiras da linha de atuação da esquerda política e estão relacionadas a direitos reivindicados por minorias e grupos sociais, cuja regulamentação depende de mediaçóes diversas e decisóes a cargo de complexos aparatos judiciais.

A esse respeito, vale notar, por exemplo, que, nos Estados Unidos, segundo Levitsky e Ziblatt (2018), os evangélicos começaram a entrar massivamente na política nos anos 1970, impulsionados pelo interesse das decisóes judiciais relacionadas ao aborto. Depois, durante o governo de Ronald Reagan, nos anos 1980, a direita cristã se associou fortemente aos cristãos evangélicos. O Partido Republicano passou a ser a preferência de $76 \%$ dos evangélicos brancos, cada vez mais envolvidos no combate ao casamento gay e à ideia de um Estado laico. Como identificou Lilla (2018, p. 354), na era Reagan, aos obsessivos defensores do livre mercado, ferrenhos cavaleiros anticomunistas e desequilibrados proponentes de teorias da conspiração, juntaram-se "líderes religiosos enojados com as mudanças culturais dos anos 1969 e - um grupo não insignificante - de mulheres conservadoras que viam no feminismo um ataque pessoal à sua qualidade de máe e dona de casa”. No contexto americano, esse autor atribui o crescimento da extrema-direita e a consequente ascensão de Donald Trump à política identitária da esquerda, que teria reforçado uma forma de individualismo baseada numa "pseudopolítica" de promoçáo da autoestima e da autodefiniçáo, principalmente entre os jovens, que, voltados para a sua própria interioridade, não foram preparados para o bem comum.

No caso brasileiro, é fato que a pauta identitária é uma bandeira das esquerdas. Contudo, enquanto no exercício do poder, a esquerda brasileira, entáo representada pelo Partido dos Trabalhadores, conjugou políticas localizadas de caráter identitário com a execução de amplos programas sociais e de recuperação da renda dos trabalhadores. Ou seja, a ênfase na redução das desigualdades econômicas, é possível argumentar, exime a esquerda de ter despendido energia em questôes identitárias ao ponto de despertar reaçóes conservadoras ou de inibir a inspiração de causas comuns. As políticas de distribuição de renda, mais do que as identitárias, acionaram o ímpeto e a agressividade da direita. Além disso, há que se avaliar se as políticas distributivas da esquerda - que incorporaram novos consumidores ao mercado - descoladas de mecanismos de aperfeiçoamento da cidadania política, não estariam por trás da exacerbação de um individualismo que propiciou o crescimento de ideologias de direita e que sempre fez parte da abordagem teológica do cristianismo evangélico.

Isto posto, podemos nos voltar para a segunda dimensão discursiva do bolsonarismo, que diz respeito à "predominância da fé sobre a razão". Ela está presente desde a campanha, quando o então candidato Jair Bolsonaro declarou: "Não tem essa historinha de Estado laico. É Estado cristáo". A frase sinalizava a intenção de incluir no seu projeto de poder, por dentro de um Estado laico desde de 1890, a subjetividade da religião cristã. Esse movimento retórico atiçou líderes evangélicos, cada vez mais confortáveis no entorno do candidato. Fechadas as urnas, a vitória da campanha bolsonarista foi celebrada com uma longa oração de um pastor-político, transmitida em todas as redes nacionais de televisão. Hoje, no governo Bolsonaro, encontram-se instaladas personalidades do segmento evangélico, mesmo em órgãos de caráter científico, como na Coordenação de Aperfeiçoamento de 
Pessoal de Nível Superior (Capes), vinculada ao Ministério da Educação. Além disso, o presidente prometeu indicar um ministro "terrivelmente evangélico" para compor o Supremo Tribunal Federal, numa das vagas que deverão se abrir naquela corte com as duas aposentadorias compulsórias previstas até 2021.

A Constituição brasileira, porém, no seu artigo 19, preceitua: "É vedado à União, aos Estados, ao Distrito Federal e aos municípios: I - estabelecer cultos religiosos ou igrejas, subvencioná-los, embaraçar-lhes o funcionamento ou manter com eles ou seus representantes relaçóes de dependência ou aliança, ressalvada, na forma da lei, a colaboração de interesse público." O partido político em construção pelos apoiadores do governo Bolsonaro, por outro lado, enfatiza no seu manifesto: "Em primeiro lugar, a Aliança pelo Brasil reconhece o lugar de Deus na vida, na história e na alma do povo brasileiro. Que é um povo religioso e solidamente educado nas bases do cristianismo e suas variadas vertentes e expressóes. [...] A relação entre Cristo e a igreja é intrinseca, fundante e inseparável". O documento claramente anuncia os valores do cristianismo ocidental como alicerces da agremiação.

Uma das consequências mais visiveis dessa reinserçâo do elemento religioso no aparato institucional de um governo no Brasil é o anti-intelectualismo. De fato, já na campanha eleitoral, apoiadores do bolsonarismo foram estimulados a hostilizar e atacar as universidades públicas, sob a complacência de instâncias judiciais inferiores, o que demandou a intervenção do Supremo Tribunal Federal para que a livre expressão do pensamento fosse assegurada no ambiente universitário. O próprio ministro da Educação do governo é agressor contumaz das universidades e observa-se entre os propagadores do bolsonarismo nas redes sociais o ataque contínuo à obras literárias, à cultura, assim como a negação da ciência. O reflexo disso se traduz em diminuição dos investimentos em pesquisa, na desconsideração em relação às instituiçóes do conhecimento - a exemplo dos conflitos entre o presidente da república e o Instituto Nacional de Pesquisas Espaciais sobre o desmatamento na Amazônia - e na grave recusa de Jair Bolsonaro em aceitar as recomendaçóes cientificas para o enfrentamento da pandemia do coronavírus. Em se tratando das universidades, não é demais mencionar a relação que Stanley $(2018$, p. 744$)$ estabeleceu entre o anti-intelectualismo e a politica fascista: "Uma vez que se deslegitimam as universidades e os especialistas, os politicos fascistas se veem livres para criar suas próprias realidades, moldadas por sua própria vontade individual". Não por acaso, os movimentos fascistas estimulam denúncias contra disciplinas com perspectivas diferentes da dominante, embora a universidade seja, desde a sua origem, um ambiente crítico e produtor do conhecimento cientifico.

A ascensäo do negacionismo cientifico foi tratada por D'Ancona (2018) no âmbito de seu trabalho sobre a pós-verdade. Para esse autor, rechaçar a ciência em questóes relacionadas à saúde pública e à segurança dos outros é especialmente preocupante. Para ilustrar, o autor cita o caso de um único estudo que vinculava as vacinas contra sarampo, caxumba e rubéola à incidência de autismo. A repercussão do estudo na mídia simplesmente resultou em queda nas taxas de imunização no Reino Unido, gerando surtos e mortes por sarampo. Com métodos insatisfatórios e conflitos de interesses evidentes, o estudo foi posto à prova por uma comissáo de cientistas que refutou, sem margem de dúvidas, qualquer relação entre as vacinas e o autismo. Após a apresentação do relatório, no entanto, a comissão responsável foi aconselhada a reforçar sua segurança em função de ameaças de violência consideradas plausiveis. Runciman (2017), por sua vez, menciona as teorias da conspiração criadas para desacreditar os cientistas que advertem o mundo a respeito das mudanças climáticas. Segundo essas teorias, as elites pretendem criar um problema global que demande ação coletiva na mesma escala. A negação do aquecimento do planeta é a arma utilizada para desacreditar o estudo cientifico e beneficiar a indústria de combustiveis fósseis.

No caso do coronavirus, o presidente brasileiro, além de minimizar reiteradamente os efeitos da pandemia, sabotando os esforços de governos locais para ampliar o isolamento social horizontal, alardeou 
a suposta eficácia de um remédio - a cloroquina - contra a Covid-19, mesmo comportamento adotado pelo presidente dos Estados Unidos. Em consequência disso, pesquisadores que realizam estudos sobre o referido medicamento foram alvo de ataques e ameaças por parte dos seguidores de Bolsonaro. A presidente de uma das principais instituiçóes de pesquisa do Brasil, a Fundação Oswaldo Cruz, ao se pronunciar sobre as ameaças, comentou:

[...] vejo como um ataque não só aos pesquisadores, mas um ataque a toda a ciência. Não por acaso, além do conselho da Fiocruz, também a Sociedade Brasileira para o Progresso da Ciência, a Sociedade de Medicina Tropical, a Academia Nacional de Medicina e várias instituiçóes científicas se posicionaram todas em favor do respeito à pesquisa científica, à preservaçấo do trabalho dos pesquisadores (UOL, 21/04/2020).

A extrema-direita brasileira repete, como se vê, a estratégia de Donald Trump, cujo governo, conforme apontou Kakutani (2018), tem sido marcado pelo ataque à ciência e aos especialistas. A razão vem sendo abandonada, assim como o debate bem informado. Trump personificou os princípios anti-iluministas, rejeitando o racionalismo, enquanto toma decisóes erráticas, por impulso, baseadas no instinto, em meros caprichos e em ideias pré-concebidas ou delirantes acerca do funcionamento do mundo. Desacreditar o jornalismo, tirar proveito da ignorância dos eleitores e manejar os seus medos e ressentimentos, sáo táticas adotas pelo presidente americano para difundir narrativas virais pela internet que servem de base para realidades alternativas. $O$ bolsonarismo se espelha nisso e tem usado os evangélicos para matar a razão e ofuscar a realidade.

Na crise da pandemia, um dos principais lideres evangélicos do pais, o pastor Silas Malafaia, tem se pronunciado sistematicamente contra a cobertura da imprensa sobre a doença, fazendo crer aos seus fiéis que o coronavirus é utilizado para promover o pânico e impulsionar a oposição política. O pastor, pertencente à vertente neopentecostal e triunfalista do segmento cristão evangélico, tornou-se um apoiador incondicional do governo Bolsonaro e aproveita a ameaça da pandemia para, perigosamente, estimular fiéis a exercitarem a fé contra a doença e a desconsiderarem as recomendaçöes científicas. O "mito" Bolsonaro, como este é chamado pelos seus mais fiéis seguidores, encontrou enfim na religiáo a simbiose conveniente para o reforço recíproco de crenças e ideologias em torno de interesses complementares.

Ao mesmo tempo, em outra direção, podemos apontar ainda uma terceira dimensão discursiva de Jair Bolsonaro: a "organização da sociedade via disciplina e ordem". A esse respeito, tendo iniciado a sua trajetória política depois de desligar-se das Forças Armadas e assumido os interesses dos militares como principal bandeira para angariar votos, Bolsonaro notabilizou-se por discursos autoritários na nova carreira. Além de posiçōes homofóbicas, machistas e de criminalização de minorias e movimentos sociais, o político Bolsonaro jamais se constrangeu em exaltar torturadores do regime militar. Não surpreende, pois, que, durante a campanha presidencial, o candidato Bolsonaro tenha chegado a falar em eliminar inimigos e matar bandidos, e prometido ocupar cargos do governo com militares. Ao menos com relação a esta última promessa, no final do primeiro ano do mandato, além do vice-presidente, o governo de fato já contava com 8 (oito) dos 22 (vinte e dois) ministérios ocupados por militares, além de mais de 2.500 (dois mil e quinhentos) outros militares em cargos de chefia e assessoramento. Na visão de Ackerman (apud RUNCIMAN, 2017), a democracia corre riscos quando os militares são cooptados pelo executivo e, subservientes, aumentam os poderes de um governo extremista. Por outro lado, a politicização dos militares pode resultar em tutela sobre o presidente. 
Porém, a opção pelo autoritarismo no discurso da campanha e como prática de governo encontrou receptividade em parte da sociedade brasileira, um reflexo da deslegitimação da política difundida nos últimos anos e da ausência de uma cultura democrática que pudesse inibir a emergência de líderes autoritários. No caso dos evangélicos, a indiferença em relação aos valores democráticos também decorre de interpretaçóes isoladas e descontextualizadas de textos bíblicos que sugerem obediência aos governantes, sujeição aos líderes religiosos e submissão à autoridade do homem no âmbito do núcleo familiar. Desse modo, a visão de uma sociedade organizada sob disciplina e ordem acomoda-se melhor nesse universo religioso. Vale notar, no entanto, que Nichols (apud GARDNER, 1982) resgatou as contribuiçóes do protestantismo para a democracia anglo-americana, identificando no movimento puritano, entre 1640 e 1650, as raízes de reformas constitucionais que favoreceram a democracia. Na Inglaterra, seja por motivaçóes religiosas com vistas a limitar as intromissóes do Estado nas práticas religiosas, seja como uma estratégia política para assegurar os direitos de minorias, calvinistas defendiam governos constitucionais. Foram, porém, os puritanos que, advogando a separação entre Igreja e Estado, desenvolveram conceitos que ajudaram no desenvolvimento da democracia política.

Ainda segundo Gardner (1982), diversos valores da democracia são condizentes com o ideário do cristianismo, a exemplo da promoção do bem-estar do povo, visto como propósito primeiro do Estado. De fato, mesmo a compreensão cristã da natureza humana, a um só tempo otimista e pessimista em relação à sua capacidade para realizar o bem, é também indicativa de que há compatibilidade entre democracia e cristianismo. Para citar as palavras de Niebuhr (apud GARDNER, 1982, p. 380): "A capacidade do homem para a justiça torna a democracia possível; mas a inclinação do homem para a injustiça torna a democracia necessária”. Além disso, convém destacar que a fé cristã ultrapassaria a norma do interesse próprio, assumindo um sentido democrático de unidade em torno do bem comum. Nesta direção, segundo esse mesmo autor, para os cristấos, assim como para os democratas, é preciso salvaguardar o reconhecimento da real humanidade de todas as pessoas, seu valor absoluto e sua verdadeira dignidade como indivíduos. Todavia, a contribuição que o cristianismo pode dar à democracia não depende da conversão de uma maioria a essa profissão de fé, devendo os que a professam tâo somente colaborar para a elevação de uma consciência pública que cresça na mesma proporção do nível de justiça social.

Gardner (1982), todavia, identificou fatores que, tal como hoje, contribuíam para que os cristãos não exercessem adequadamente sua responsabilidade política, dentre os quais se destacam: a ideia de que a política é algo sujo, a falta de compreensão das relaçóes de forças que envolvem o poder político, o receio da controvérsia, o preconceito contra os esforços cooperativos e sociais, a ausência de discernimento quanto aos reais problemas da sociedade e a ênfase em personalidades e/ou assuntos particulares de cunho moral. Assim, a omissão, o ceticismo, a autorretidáo e uma participação difusa e débil, acabavam por contribuir para a injustiça social.

O fato é que a redução dessa forma de injustiça está relacionada a maiores graus de democracia. Arretche (2018) demonstrou que as desigualdades de renda tendem a diminuir em contextos de mais participação eleitoral e que nestes as demandas dos menos favorecidos são melhor vocalizadas. A democracia e a justiça social, no entanto, não estiveram nos critérios determinantes da maioria dos evangélicos cristãos nas eleiçóes brasileiras de 2018. Tal como atestam as pesquisas, em torno de $70 \%$ desse grupo social optou por um candidato autoritário. Sobre isso, Levitsky e Ziblatt (2018, p. 396) alertaram: "Se o povo abraça valores democráticos, a democracia estará salva. Se o povo está aberto a apelos autoritários, então, mais cedo ou mais tarde, a democracia vai ter problemas". Esses autores listaram os critérios para avaliar se um líder é autoritário, a saber: a rejeição às regras 
democráticas do jogo, a negação da legitimidade dos oponentes políticos, a tolerância ou o encorajamento à violência, a propensão a restringir liberdades civis de oponentes, inclusive da mídia. Em menos de um ano e meio de governo, Bolsonaro já disse que as eleiçôes de 2018 foram fraudadas (embora tenha vencido), promove a criminalização de adversários políticos, estimula a prática de eliminação de criminosos e se tornou num contumaz agressor da mídia tradicional. Ainda assim, os evangélicos continuam formando o grupo mais fiel ao seu governo.

Por fim, o quarto elemento discursivo manejado por Jair Bolsonaro e mais facilmente eficaz quando dirigido ao público evangélico é o marcathismo. A esse respeito, como lembram Levitsky e Ziblatt (2018), nos próprios Estados Unidos, em várias circunstâncias históricas, as regras democráticas foram desafiadas e as instituiçóes ameaçadas. Num desses momentos, no final dos anos 1950, o macarthismo ascendeu, espalhando o temor entre os cidadãos americanos no contexto da Guerra Fria, quando a antiga União Soviética surgira como potência nuclear. A histeria anticomunista liderada pelo senador Joseph McCarthy foi usada para perseguir pessoas e estigmatizar oponentes. Desesperados por um novo apelo eleitoral eficaz, os conservadores do Partido Republicano instrumentalizaram o anticomunismo como um "porrete" para derrotar os Democratas. A virulência da tática macarthista assaltou as normas de tolerância mútua até que caísse em descrédito, restringindo-se a grupos extremistas que mantiveram vivo o espírito do anticomunismo.

Finda a Guerra Fria, derrubado o muro de Berlim há mais de trinta anos e tendo o capitalismo assumido a hegemonia no mundo ocidental, as sombras da ameaça comunista foram ressuscitadas para se agregar às estratégias da extrema-direita, no objetivo de inibir o debate democrático e turvar a percepção dos cidadãos. Apelando para um inimigo hoje genuinamente imaginário e associando-o a qualquer menção às políticas, causas ou reivindicaçóes de caráter social, a retórica difundida pela extrema-direita combinou clichês nacionalistas (“A nossa bandeira jamais será vermelha!") com a criminalização de políticas públicas destinadas aos mais pobres, num processo amparado por narrativas de formadores de opinião nos meios de comunicação. A junção desses mecanismos expressou-se mais claramente na reação dos setores conservadores ao Programa Mais Médicos, política pública destinada a levar atendimento básico de saúde às periferias e regióes isoladas do Brasil, viabilizada principalmente pela presença majoritária de médicos cubanos. O programa, apesar da elevada aprovação popular verificada entre os beneficiários, foi hostilizada enquanto durou e abandonada pelo governo de extrema-direita por motivaçôes exclusivamente ideológicas.

Já o macarthismo direcionado aos evangélicos repetiu a fórmula de associar a esquerda política ao pensamento secular e ateísta que vê a religião como um fator de alienaçáo e de impedimento de um progresso que prescinde da moral cristã. O Brasil já foi governado por um presidente declaradamente ateu, Fernando Henrique Cardoso. No entanto, o fato de situar-se no espectro conservador da correlação de forças da sociedade brasileira impediu, durante todo o seu governo, qualquer antagonismo entre ele e os religiosos. Já em 2018 o cenário era outro. E, na mistura de ingredientes do caldo cultural e político criada para derrotar as esquerdas, não podiam faltar as mistificaçóes promovidas pelo macarthismo tropical, que de fato "demoniza" as esquerdas, assassinando reputaçóes e suscitando o medo e a raiva, também entre os que foram induzidos a contrapor o social à sua fé individual. É por essa via que o macarthismo estimula o preconceito da religião contra o pensamento de esquerda.

Tonet (2016) explica que a notória desconfiança da religião em relação à teoria marxiana decorre da conexão entre esta última e o ateísmo. Para o autor, de fato é possível agrupar as divergências entre a religiosidade e a concepção marxiana da emancipação humana em seis questóes principais: 1) a prioridade da matéria sobre o espírito ou vice-versa; 2) a existência ou não de um mundo 
transcendente; 3) a origem do ser social; 4) a existência de teleologia na história humana ou no interior do ser social; 5) a explicação imanente ou transcendente dos acontecimentos (com propósitos previamente definidos ou resultantes da ação humana); e 6) a questão da origem e natureza do mal. Estas questóes, ainda segundo Tonet (2016), só podem ser resolvidas pelo processo histórico. A seu ver, não há como chegar a nenhum acordo a respeito delas. $\mathrm{O}$ fato é que, apesar de prováveis consensos em torno da transformação social, o imperativo da supressão da propriedade privada e da extinção do Estado é inegociável. Assim sendo, o desaparecimento da religião numa sociedade comunista seria resultado natural da busca de uma emancipação fundada na compreensão de que a realidade social é exclusivamente decorrente da atividade humana. Em face disso e talvez por isso, aludindo a uma máxima do próprio Karl Marx, mencionada por Tonet (2016, p. 149): "Devese duvidar de tudo", os religiosos prefiram a fé, ainda mais em realidades nas quais as soluçóes humanas de ordem política mostram-se desacreditadas. Por outro lado, esses mesmos religiosos não conseguem decifrar os interesses que se camuflam quase que de forma invisível para reafirmar dominaçôes em nome de Deus.

\section{CONSIDERAÇõES FINAIS}

A narrativa e o discurso são capitais simbólicos determinantes na arena política. Em tempos de redes sociais, a extrema direita saiu na frente na estratégia de conquistar eleitores em diversos contextos. Apelando a crenças e preconceitos, o populismo de direita tem logrado manejar medos e ressentimentos, ameaçando as democracias ocidentais. $\mathrm{O}$ fortalecimento do conservadorismo resgata tradiçóes e tenta impor o retorno a um passado mítico. Nesta direção, encontra nos segmentos religiosos o público mais suscetível aos seus discursos.

No Brasil, esses discursos encontraram em amplos setores da religião evangélica um suporte determinante para a ascensão da extrema direita. Além de decisivo durante as eleições, a aliança entre extrema-direita e religião evangélica produziu uma argamassa de apoio social ao governo eleito, apesar dos conflitos, contradiçóes e retrocessos por ele gerados. Esse apoio pode ser classificado em três frentes.

Em primeiro lugar, os evangélicos lhe oferecem um apoio "ideológico", reforçando os discursos do governo difundidos nas redes sociais. Ativos nessas plataformas, crentes praticam as suas tendências messiânicas replicando todas as teses do governo, mesmo quando estas contradizem princípios do cristianismo. Em segundo lugar, o apoio evangélico se dá sob a forma "parlamentar". A bancada evangélica, historicamente ligada às pautas conservadoras, tornou-se na parcela do congresso mais identificada com as premissas da extrema-direita e a ela disponibiliza votos para as medidas governamentais. Por último, os evangélicos oferecem apoio "eclesiástico". Eventos e liturgias (oraçóes, jejuns e cultos) têm sido frequentemente utilizados para enaltecer ou defender o governo Bolsonaro. Estruturas de igrejas foram mobilizadas para angariar assinaturas necessárias para o registro de um novo partido idealizado por Bolsonaro e seus seguidores. Considerando-se a representatividade dos evangélicos na demografia e no voto, não é pequeno o impacto que suas opçóes políticas têm sobre a democracia brasileira. As eleiçôes de 2018 e a sobrevivência do governo Bolsonaro já demonstrou isso, como aqui se tenta elucidar.

Está claro que o governo Bolsonaro não tem a intenção de amparar-se numa maioria da população. Persegue o objetivo de conservar um núcleo duro de apoio social, suficiente para contrapor-se a 
um polo oposto - sempre criando fatos que preservem o antagonismo com esse polo e alimentando a percepção de que ele é formado por radicais perigosos e desprezíveis - para vencer eleiçôes pelo ódio e o medo, assim como manter-se no poder emulando crenças e valores úteis a essa estratégia.

Assim, a democracia brasileira enfrenta hoje o desafio de criar espaços de comunicação públicos que permitam um diálogo plural capaz de romper as bolhas criadas pelo extremismo de direita. Dentre essas, os religiosos e particularmente os evangélicos, apresentam maior grau de coesão em torno da agenda da extrema-direita pelos motivos aqui expostos. Até agora, o lento arrefecimento da base de apoio do bolsonarismo, apesar do comportamento errático e cada vez mais autoritário do governo, deve-se sobretudo à insistência dos evangélicos em manterem o encantamento pelo mundo a partir de suas crenças, comportamento útil ao projeto da extrema-direita para, por vias eleitorais e de controle do Estado, desmontar os sistemas democráticos.

\section{REFERÊNCIAS}

ANDRADE, R.O. Novos arranjos nos lares brasileiros. Pesquisa Fapesp, Ed. 263, Janeiro, 2018.

ARRETCHE, Marta. Democracia e redução da desigualdade econômica no Brasil: a inclusão dos outsiders. Revista Brasileira de Ciências Sociais [online]. 2018, vol.33, n.96, e339613. Epub Jan 08, 2018.

BOAS, Taylor C. Evangelicalism, conservative parties and voting behavior in Latin America. In: CONFERENCIA “FINDING RELIGION” DO INSTITUTE ON CULTURE, RELIGION, AND WORLD AFFAIRS, 1., 2019. Anais... Boston: Universidade de Boston, 29 mar. 2019. Disponível em: < http://people.bu.edu/tboas/evang_voting_behavior.pdf>. Acesso em: 10 maio 2020.

BRPOLÍTICO. Questão moral pesa mais que renda para eleitorado pobre, diz pesquisa. Disponível em: <https://brpolitico.com.br/noticias/questao-moral-pesa-mais-que-renda-para-eleitorado-pobre-diz-pesquisa/>Acesso: 13/04/2020.

DATAFOLHA. Eleiçóes 2018: Brasil - Intenção de voto para presidente da República - 2º turno - 25/10, 2018. Disponível em: < http://media.folha.uol.com.br/datafolha/2018/10/26/341 6374d208f7def05d1476d05ede73e.pdf>. Acesso em: 10 maio 2020.

D’ANCONA, Matthew. Pós-verdade: a nova guerra contra os fatos em tempos de fake News. Barueri, São Paulo: Faro Editorial, 2018.

FINCHELSTEIN, Federico. O líder fascista como encarnação da verdade. Brasília: Revista Serrote, 01/05/2020.

GARDNER, E.C.. Fé bíblica e ética social. Rio de Janeiro: Juerp, 1982.

KAKUTANI, Michiko. A morte da verdade. Editora Intrínseca, ASIN B07GDTWP3M, 2018.

LEVITSKY, S.; ZIBLATT, D.. Como as democracias morrem. Rio de Janeiro: Zahar, 2018. 
LILLA, Mark. O progressista de ontem e o do amanhá: desafios da democracia liberal no mundo pós-política identitárias. São Paulo: Companhia das Letras, 2018.

MARIANO, Ricardo; GERARDI, Dirceu André. Eleiçôes presidenciais na América Latina em 2018 e ativismo político de evangélicos conservadores. Revista USP, São Paulo, n. 120, p. 61-76, jan./fev./mar. 2019.

RUNCIMAN, David. Como a democracia chega ao fim. São Paulo: Todavia, 2017.

STANLEY, Jason. Como funciona o fascismo: a política do nós e eles. Editora L\&PM, ASIN 8525438200,2018 .

TONET, Ivo. Marxismo, religiosidade e emancipaçáo humana. Maceió: Coletivo Veredas, 2016.

UOL. Ataques ameaçam trabalho científico, diz presidente da Fiocruz. Disponível em: <https://noticias.uol. com.br/colunas/chico-alves/2020/04/21/ataques-ameacam-trabalho-cientifico-diz-presidente-da-fiocruz. htm>Acesso em 21/04/2020. 